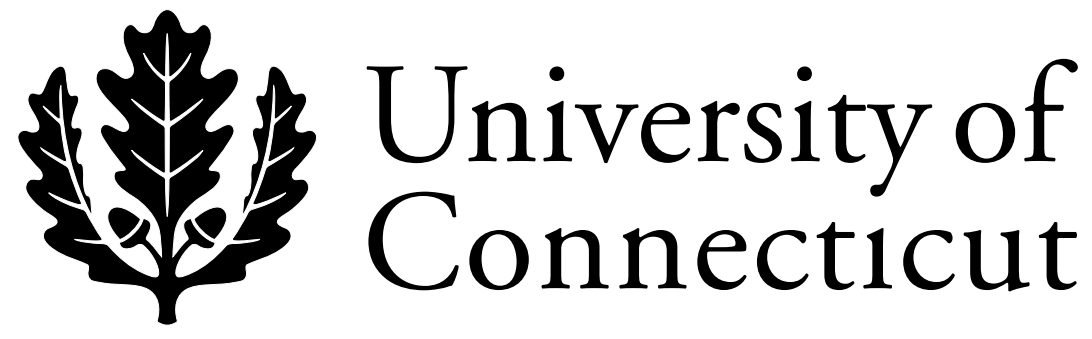

Department of Economics Working Paper Series

Risk, Transaction Costs, and Tax Assignment: Government Finance in the Ottoman Empire

Metin M. Cosgel

University of Connecticut

Thomas J. Miceli

University of Connecticut

Working Paper 2003-04

January 2003

341 Mansfield Road, Unit 1063

Storrs, CT 06269-1063

Phone: (860) 486-3022

Fax: (860) 486-4463

http://www.econ.uconn.edu/ 


\begin{abstract}
This paper examines the effects of risk and transaction costs on the allocation of tax revenues, commonly known as the tax assignment problem: who should tax what and how in a multi-level system of government? Tax assignment was an important problem for the Ottoman state, which by mid sixteenth century had built a vast Empire that covered much of the Middle East, North Africa, and Eastern Europe. The Empire collected revenues from various types of taxes and assigned these revenues between the central, provincial and district governments, and other recipients like fiefholders and pious foundations. Tax revenues were of two types, fixed taxes and variable taxes, which differed in their risk and transaction cost for the recipient. To understand how tax revenues were assigned, we examine how recipients varied in their capabilities to deal with risks and transaction costs. Formulating the competing implications of the risk and transaction cost explanations as testable hypotheses, we test them quantitatively with data from tax registers. The results show that in most regions tax assignment was influenced more by transaction costs than risks, suggesting that there were feasible alternatives for the recipients to insure against risk.
\end{abstract}

We wish to thank the participants and discussants at the 2002 Annual Cliometrics Conference in La Crosse, WI and the 2003 Social Scie nce History Association meetings in Baltimore, MD for helpful comments and suggestions. Ali Ozdemir, Sadik Yildirim, and Hoseyin Yilmaz provided valuable research assistance. 


\title{
RISK, TRANSACTION COSTS, AND TAX ASSIGNMENT: GOVERNMENT FINANCE IN THE OTTOMAN EMPIRE
}

\begin{abstract}
This paper examines the effects of risk and transaction costs on the allocation of tax revenues, commonly known as the tax assignment problem: who should tax what and how in a multi-level system of government? Tax assignment was an important problem for the Ottoman state, which by mid sixteenth century had built a vast Empire that covered much of the Middle East, North Africa, and Eastern Europe. The Empire collected revenues from various types of taxes and assigned these revenues between the central, provincial and district governments, and other recipients like fiefholders and pious foundations. Tax revenues were of two types, fixed taxes and variable taxes, which differed in their risk and transaction cost for the recipient. To understand how tax revenues were assigned, we examine how recipients varied in their capabilities to deal with risks and transaction costs. Formulating the competing implications of the risk and transaction cost explanations as testable hypotheses, we test them quantitatively with data from tax registers. The results show that in most regions tax assignment was influenced more by transaction costs than risks, suggesting that there were feasible alternatives for the recipients to insure against risk.
\end{abstract}

Economic historians have explained various institutions and organizations by examining how risk and transaction costs differ among alternative arrangements and how economic agents have differential capabilities to deal with them. In a hypothetical world without risks or transaction costs, it may make no difference for the use of resources how production and exchange activities are organized. But in a world complicated by risk and transaction costs, various interesting organizations and institutional arrangements emerge as direct outcomes of choices subject to these considerations. Emphasizing risk and transaction costs have helped to understand a variety of phenomena in history, including sharecropping, the Open Field system and enclosures, the emergence of the firm, and the contractual structures observed in slavery, manorial system, and Southern agriculture. 1

\footnotetext{
${ }^{1}$ See, for example, Alston and Higgs (1982), Cheung (1969), Coşgel (1992), Fenoaltea (1976), McCloskey (1976), and Stiglitz (1974).
} 
Emphasizing risk and transaction costs can also help to answer one of the fundamental questions of public finance known as the tax assignment problem: who should tax what and how in a multi-level system of government (McLure, 1983)? If the risk and transaction costs of tax bases vary significantly and the recipients of taxes have different capabilities in dealing with them, then these differences may have been the basis for tax assignment. Risks can affect the tax system if some tax revenues are subject to region-specific shocks. It may be more optimal for these revenues to be assigned to the central government than local governments, because the central government may be in a better position to diversify risky revenues across regions. Transaction costs can also affect the tax system if, for example, it is costlier to measure the tax base of some types of taxes than others and if different levels of government differ in their abilities to bear these costs.

This paper will examine how risks and transaction costs affected tax assignment in the Ottoman Empire during the sixteenth century. By mid sixteenth century, the Ottomans had built a vast Empire that spanned the area between the Black Sea in the north to Egypt and the Arabian Peninsula in the south, and between the Persian Gulf in the east to central Europe and North Africa in the west. Combining elements from the customs and administrative practices of preceding states and the basic principles of Islamic taxation, they developed a system of government finance that assigned tax revenues to various recipients, including the central treasury, provincial and district governments, military personnel, and various other agents like tribes and pious foundations.

To determine how risk and transaction costs affected the assignment, we categorize taxes into two groups based on whether the tax base was fixed or variable during the taxation cycle and examine how risks and transaction costs differed between the two groups. We also examine 
the differential capabilities of the recipients of taxes in bearing the risks and transaction costs. The tax assignment problem can be summarized as two competing hypotheses. According to the risk hypothesis, tax revenues with a fixed (safe) base should be allocated to local governments and those with a variable (risky) base should go to the central government. The opposite should happen according to the competing transaction cost hypothesis: tax revenues with a fixed (cheap to measure) base should be assigned to the central government and those with a variable (expensive to measure) base should go to local governments (who can bear the cost more efficiently). Testing these hypotheses quantitatively with data from the Ottoman tax registers of the sixteenth century, we find that the tax assignment was influenced more by transaction costs than risks.

\section{RISKS, TRANSACTION COSTS, AND TAX ASSIGNMENT}

Risk and transaction costs are often the focus of competing explanations of historical phenomena. Consider the well known explanations of land scattering observed in the Open Field system. In a pioneering contribution that championed economic approaches to such phenomena, McCloskey (1976) argued that this peculiar pattern of holding land was simply a mechanism for peasants to insure against risk. ${ }^{2}$ But in another pioneering contribution, Fenoaltea (1976) emphasized transaction costs, rather than risks. Noting "considerations of risk and transaction costs have altogether different implications for the organization of medieval agriculture," he found the key to scattering in the transaction costs of purchasing or exchanging labor (Fenoaltea, 1976: 130).

\footnotetext{
${ }^{2}$ See Persson (2003) for a historical overview of various institutions designed for the management of agricultural risk.
} 
Consider, as another well-known example, explanations of sharecropping (or agricultural contracts in general) observed throughout history. Although there are several economic approaches to contracts, two of the dominant and competing approaches have been the principal-

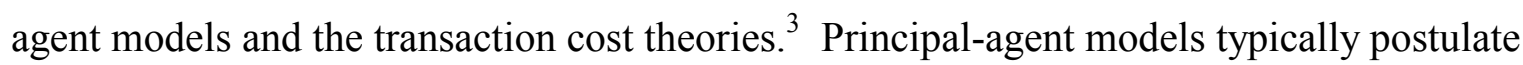
different risk attitudes between contracting parties and examine the tradeoff between the risk and incentives associated with alternative contractual forms to explain why sharecropping was observed (Cheung, 1969; Stiglitz, 1974). Transaction cost theories, on the other hand, avoid making assumptions about risk preferences (or assume universal risk neutrality) and instead focus on differences in the various costs of negotiating, supervising, and enforcing contracts.

Although theories of risk and transaction costs have originally been developed to explain private organizations and institutions, these ideas can also be used to study the public sector. Some of the recent studies of taxation and government expenditures have indeed relied heavily on these concepts. Aronsson and Wikström (2003), for example, examine optimal taxation and risk sharing arrangements in an economic federation. Similarly, Patashnik (1996) studies the implications of transaction cost theory for the design of budgeting institutions. ${ }^{\text {G }}$ The effect of risk and transaction costs on the assignment of tax revenues in history, however, has not been systematically examined.

To examine how risk and transaction costs can affect tax assignment, consider a twotiered governmental structure consisting of a central government and multiple local

\footnotetext{
${ }^{3}$ For a historical overview of agricultural contracts, review of the pertinent literature, and quantitative analysis of some of the proposed hypothesis, see Allen (1998), Alston (2003), Alston and Higgs (1982).

${ }_{5}^{4}$ See, for example, Allen and Lueck (1993).

${ }^{5}$ For examples of other studies of public finance based on theories of risk and transaction costs, see the references cited in Aronsson and Wikström (2003: 104-106) and Patashnik (1996: 190).
} 
governments. Suppose that aggregate tax revenues will be allocated among these various governments in pre-set proportions. (That is, the spending side of the public budget has already been determined.) For simplicity, suppose there is a single local government, and aggregate tax revenue, $R$, will be divided between the central and local governments as follows:

$$
R=R_{C}+R_{L}
$$

Tax revenue is generated from two sources, fixed taxes and variable taxes, , which differ both in their predictability and measurability. Fixed taxes are those that do not change during the taxation cycle. This can happen because, for example, the tax base depends on a fixed asset or a fixed input used in production. Examples include property taxes and taxes that depend on inputs like the number of trees or the quantity of land, observed frequently throughout history. The tax revenue from fixed taxes is easier to predict and measure because the tax base is stable over time and relatively easy to observe. In contrast, variable taxes are those that can change considerably during the taxation cycle. They are typically based on the revenue or profits from the production or sale of a good or service, which can change over time and by region due to weather, varying fertility of land, and other aspects of the production process. To capture this difference in the simplest manner, we treat total revenue from fixed taxes, $F$, as determinate, and total revenue from variable taxes, $V$, as random. In any given budgetary period, expected revenue must equal total expenditures:

$$
F+E(V)=R_{C}+R_{L}
$$

The problem facing the central government is how to distribute tax revenues between the central and local governments. In a world in which both levels of government are risk-neutral

See also contributions in Part III of Hoff, Braverman, and Stiglitz (1993) for applications to agricultural taxation. 
and the transaction costs of raising revenue are zero, the allocation of the two types of taxes between the two types of governments does not matter, so long as (2) is satisfied. The two levels of government may differ, however, both in their aversion to risk and their costs of generating revenue. When this is true, there may exist an optimal allocation of fixed and variable taxes between them. We first consider differences in their attitudes toward risk.

The central government, because it receives revenue from all parts of the Empire, can diversify away most of the risk from variable taxes, whereas local governments cannot. To capture this, we assume that the central government is risk neutral, while the local government is risk averse. In this case, it is clearly optimal for the central government to fully insure the local government against revenue risk by collecting all of the tax revenue and then redistributing it to the local government in the form of a grant to cover its spending. Such a scheme, however, assumes that it is costless to redistribute revenue between governmental levels, given that all revenue is, in effect, raised locally. If such costs matter, then the above scheme can be approximately duplicated by financing as much local spending as possible out of fixed taxes.

Specifically, suppose $F \geq R_{L}$. In this case, all local spending can be financed by fixed taxes, and any remaining fixed tax revenue, plus all variable tax revenue, can be transferred to the central government to finance its spending, where it follows from (2) that

$$
R_{C}=\left(F-R_{L}\right)+E(V)
$$

Note that this scheme duplicates the first-best outcome, and the local government is fully insured against revenue risk. Alternatively, if $F<R_{L}$, then all fixed taxes plus some variable taxes must be used to finance local spending, while the remaining variable taxes are transferred to the

\footnotetext{
${ }^{6} \mathrm{We}$ do not address the question of which type of tax is optimal in terms of revenue generation, assuming instead that some mix of the two taxes maximizes revenue.
} 
central government. This represents a second-best outcome because the local government bears some residual revenue risk.

The preceding argument assumed that the local and central governments differed in their abilities to absorb risk, but there is another dimension along which they might differ--namely, the transaction cost of generating revenue. This cost involves such things as measuring the tax base to prevent tax evasion, and agency costs associated with bribery of, or theft by, tax collectors. Suppose these costs are lower for the local government because it is "closer" to the source of the taxation as compared to the central government.

To capture this, let $R_{v}\left(1-m_{j}\right)$ be the "effective revenue" that can be raised from a given variable tax, $\mathrm{Z}_{\text {where }} m_{j}$ is the proportion of the gross tax that is dissipated when the tax is collected by government level $j, j=L, C$. Our assumption that the central government has higher transaction costs implies that $m_{C}>m_{L}$. To isolate the transaction cost effect, we assume that both governments are risk neutral.

Given this specification, it is clearly optimal for all variable taxes to be collected by agents of the local government in order to minimize transaction costs. (It does not matter how fixed taxes are collected.) If redistribution of revenue is costless, then, given universal risk neutrality, the manner in which the tax revenue is allocated does not matter. However, if redistribution of revenue is costly, then the differential transaction costs of collection would suggest that local spending should be financed as much as possible out of locally raised variable taxes, while the central government should be financed primarily out of fixed taxes. Such a

\footnotetext{
${ }^{7}$ We assume for simplicity that only the variable taxes are subject to this transaction cost. This reflects the greater unpredictability of these taxes, which creates wider scope for evasion or confiscation.
} 
scheme jointly minimizes the transaction costs of raising revenue and of redistributing revenue between government levels.

The preceding analysis has generated opposing predictions regarding the allocation of revenue between the central and local governments. If risk-sharing is the primary consideration, then revenue from variable taxes should be allocated to the central government because of its superior ability to bear revenue risk. In contrast, if the transaction cost associated with revenue collection and distribution is the primary consideration, then variable tax revenue should be assigned to local governments because they are in a better position to minimize revenue dissipation.

\section{OTTOMAN TAX CATEGORIES}

To examine the risk and transaction cost hypotheses in the Ottoman Empire, we use information from the Ottoman tax registers, conducted periodically by the government to obtain

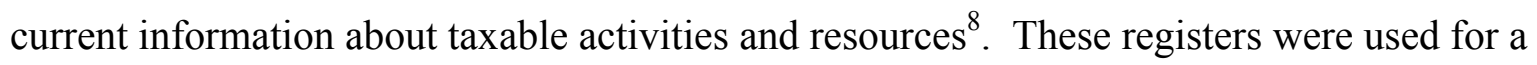
variety of purposes, including serving as official registers to establish legal claims to land, assessing the empire's expected tax revenues, and appropriating these revenues to different levels of the government.

At the beginning of each district's register was its tax code, laying down the basic tax regulations of the district and specifying the rates for each type of tax. The tax codes and other information recorded in the registers can be used to classify Ottoman taxes into the general

\footnotetext{
${ }^{8}$ These registers were called defter-i hākanī [imperial register], commonly known as the tahrir defterleri (s. defter). For the contents and potential uses of these registers, see Coşgel (2003).
} 
categories of fixed and variable taxes. ${ }^{\square}$ In the fixed category were the personal taxes that were based on a taxpayer's marital and economic (e.g., land ownership) status, input taxes that were based on one of the inputs (e.g., land, trees, animals) used in production, and lump-sum taxes that were collected from some of the small, distant villages and from most of the service and manufacturing activities in towns. Variable taxes included trade taxes that were based on the sale of goods in market towns and output taxes (primarily on grains, legumes, and fibers) that were assessed as a share of the total output (like the tithe). 10

Table 1 shows examples of tax types and rates in some districts of the Ottoman Empire that represent its geographical diversity during the sixteenth century. ${ }^{4}$ Jerusalem (Kudüs) is in eastern Mediterranean, Budapest (Budin) is in Europe, Bursa (Hüdavendigār) is in western Anatolia, Erbil is in northern Iraq, and Antep and Malatya are in eastern Anatolia. Examples of taxes and rates similarly represent commonalities and regional differences, showing how local conditions affected the tax system. The table does not include examples of lumpsum taxes, because the tax codes typically did not codify standardized rates for these activities (except for some rare occasions, such as when they specified the tax rates for retail stores as "per store").

\footnotetext{
${ }^{9}$ Ottoman taxes have also been classified according to their historical origin, legal foundation, method of payment, and the recipient of the tax revenue. See, for example, Inalc1k $(1959,1994)$ Kazıcı (1977), and Darling (1996).

${ }^{10}$ The Ottoman central government also received revenues from other sources like tributes from vassal states and profits from government owned enterprises. Because of our focus on tax assignment, such revenues are excluded from this classification. Extraordinary levies to the state called avar1z-1 divaniyye are also omitted because of their irregular nature during the classical age. For Ottoman state revenues, see İnalc1k (1994: Vol. 1, pp. 55-76). See also Løkkegaard (1950) and Lambton (1962) for Islamic taxation in general.

${ }^{11}$ See Akgündüz (1990) and Barkan (1943) for the complete tax codes of these and other districts.
} 
The risky portion of the Ottoman tax revenues from the recipient's perspective consisted of trade and output taxes. Trade taxes were risky because the amounts of goods brought to the market could fluctuate based on market cycles and various local conditions. Output taxes were also risky because they were subject to various locality specific shocks like the weather, climate, and other natural conditions. The revenue from personal, input, and enterprise taxes, on the other hand, were more certain from the recipient's perspective. The amount that the taxpayers owed for these taxes did not (in principle) depend on business or weather conditions. For example a married landholding peasant still owed the yoke (çift) tax when his crop failed one year. He similarly owed input taxes on his fruit trees even if the fruits were ruined in a storm. The recipient of taxes could thus expect his income from fixed taxes to be steady.

Transaction costs could also be different between the fixed and variable Ottoman taxes, because the cost of administering and collecting taxes was significantly higher for trade and output taxes than for personal, input, and enterprise taxes. Measurement costs, for example, could be very high. ${ }^{2}$ For trade taxes the recipient had to determine the quantity of taxable items brought to the market for sale each market period, because the quantity could not be predetermined or easily estimated. It could be easy to hide and difficult to measure the tax base, requiring the recipient to incur cost for accurate measurement. The recipient similarly had to incur cost to determine the value of total output for output taxes, which could also be easy to hide and difficult to measure. For personal, input, and enterprise taxes, on the other hand, transaction costs could be negligible. It was significantly cheaper to measure the quantities of persons, shops, and trees than the output of grain or the quantity of items brought for sale.

${ }^{12}$ Allen and Lueck (1993) emphasize measurement costs to explain cropsharing contracts in modern agriculture. See also Barzel (1982) for the general importance of measurement cost for the organization of markets. 


\section{TAX ASSIGNMENT IN THE OTTOMAN EMPIRE}

The Ottoman government consisted of multiple hierarchical levels that divided the Empire into provinces, provinces into districts, and districts into fiefs. Offices at each level received income from taxable sources assigned by the central government. Although a small number of taxes were sometimes assigned exclusively to certain levels of government, tax assignment was generally based not on the type of taxes but the taxpayer. That is, the system did not assign output taxes exclusively to, say, central government and all other taxes to other recipients. Instead, revenues were distributed by taxpayer. Whereas everyone in one village paid taxes to the central government, their neighbors in the next village paid to the provincial government, and those in other villages paid to the district government, or a local fiefholder (cavalrymen or military commander), or a pious foundation. ${ }^{13}$ Table 2 reports the distribution of tax revenue among the main groups of recipients. 14

Although fixed and variable taxes were not exclusively assigned to recipients, this did not mean that the assignment of taxes did not consider differences between fixed and variable taxes, because the proportions of these taxes could vary among taxpayers. To test the implications of the risk and transaction cost hypotheses for tax assignment in the Ottoman Empire, we thus need

\footnotetext{
13 The main revenue recipients were the central government (variously denoted in the registers of different regions as, for example, hāss-1 şāhī or hāss-1 humāy $\bar{u} n$ ), provincial administrators such as the governors of provinces ( $m \overline{\mathbf{1}} r m \overline{\mathbf{1}} r \overline{\mathrm{a}} n$, paşa, beylerbeyi) or districts ( $m \overline{\mathbf{1}} r$ liwā, sancakbeyi), and holders of small and large fiefs ( $t \bar{\imath} m \overline{\mathrm{a}} r$ and $z a$ 'āma). There were also pious foundations ( $v a k l f s$ ), private landholders ( $m \ddot{u} l k$ ), and tribal leaders, who somehow possessed the right to collect tax revenues from some villages, based on rights recognized by the legal system or preserved after conquest for political reasons. For the organization and financing of the Ottoman government, see İnalc1k (1973), Kunt (1983), and Darling (1996).

${ }^{14}$ For examples of the distribution of tax revenues in other districts, see Barkan and Meriçli (1988: 5).
} 
to examine not how fixed and variable taxes were allocated exclusively to recipients but how their proportions affected the assignment. Consider first the risk hypothesis. Suppose the tax revenue of a village consisted mostly, if not exclusively, of output taxes that were subject to location-specific shocks. Because the central government received revenue from all parts of the empire and thus had a well diversified budget portfolio, it would have mattered little to the risk level of the central treasury to add this highly risky income to its portfolio. This was also true for the tax revenues of a provincial government, though to a lesser degree because its revenues were typically restricted to the province (Kunt, 1983). A fiefholder, on the other hand, typically received income from a single village or only a few villages. By receiving this village's tax revenue, he would have been exposed to high risk without an ability to diversify. The risk hypothesis would thus imply that this village's tax revenues should be assigned to the provincial or central governments rather than a local fiefholder.

The transaction cost hypothesis implies the opposite about the assignment of this village's tax revenues. The central government collected taxes through hired agents, who could lack sufficient knowledge of local production technologies and units of measurement required for accurate measurement of variable tax bases (quantity and quality). Moreover, it was not in their interest to measure the tax base accurately, because their income was independent of the tax revenue. At the other extreme were the fiefholders who collected taxes from their villages of residence and depended on the tax revenue for their livelihood (Kunt, 1983: 13). Unlike the agents of the central government, fiefholders had the knowledge, ability, and high incentives for accurate measurement of variable tax revenues. Between the central government and local fiefholders were other levels of government that were situated at different distances to the tax 
source, incurring correspondingly high levels of transaction costs. ${ }^{5}$ The transaction cost hypothesis would thus imply that the tax revenue of a village with a high proportion of output taxes should be assigned to a fiefholder, rather than the provincial or central government.

\section{A QUANTITATIVE ANALYSIS OF THE EFFECT OF RISK AND TRANSACTION COST ON TAX ASSIGNMENT}

For a quantitative analysis of the risk and transaction cost hypotheses of tax assignment, we use data from the tax registers of various regions of the Ottoman Empire. To formalize the two hypotheses in testable form, we constructed a qualitative "distance" variable that represents the relationship between the source and recipient of a tax revenue. We ranked recipients based on their distance to the taxable source in an ascending order, starting with private landholders, then the fiefholders, pious foundations, the district government, the provincial government, and finally the central government. Then we created an ordinal variable that took the value of the recipient's rank order: the value was 1 if a village's tax recipient was a private landholder, 2 if a small fiefholder, and so on. 16 The distance was the greatest for the central government. This variable served as the dependent variable in an ordered probit model.

\footnotetext{
${ }^{15}$ The argument also applies to pious foundations that received revenues to support charitable activities. The transaction cost was likely to be lower for pious foundations than provincial or central governments because of their clear beneficiaries and local operations and management The beneficiaries of a foundation were likely to apply strong pressure for higher revenues, changing the nature of the agency problem. Although the manager(s) of a foundation may not have received all tax revenues directly as remunerations for service, they were ultimately responsible for the provision of these services and thus had high incentives to maximize tax revenues in order to fulfill professional obligations and improve service.

${ }^{16}$ Because of the hierarchical nature of the Ottoman system of government, the values for government offices also correspond to their order in the hierarchy. Although some of the recipients, such as private landholders and pious foundations, were not part of the Ottoman government, they received revenues that could have been allocated to the government. We thus kept the information about the allocation of such revenues in the quantitative analysis.
} 
The explanatory variable of primary interest is the proportion of variable taxes in total taxes. The sign of this variable would show which of the risk and transaction costs considerations were more dominant in the allocation of tax revenues. If the sign turns out to be positive and significant, it will support the risk hypothesis. It will indicate that, all else being the same, the riskier tax revenues were more likely to be allocated to distant recipients, who could better deal with risks as part of their increasingly more diverse portfolio of revenues. But if the sign turns out to be negative, it will support the transaction cost hypothesis, indicating that costlier revenues were more likely to be assigned to closer recipients, who could better deal with these costs.

To isolate the effect of the proportion of output and trade taxes in the regression analysis, we included variables that control for other influences on the determination on the tax recipient. The size of the tax source, for example, could be a factor. Provincial and central governments may have preferred large sources of revenue in order to benefit from economies of scale in tax collection (for example by reducing the travel and set up costs of their agents) $\frac{17}{\text {. To consider }}$ this possibility, we included the number of taxpayers in a village as a proxy variable for its size. The tax revenues of some villages were divided between two or more recipients. Because the division of revenue required costly coordination, distant recipients may have been reluctant to collect revenues from such villages. To determine whether this had any effect on revenue allocation, we generated a dummy variable based on whether a village's tax revenue was divided

Whenever the records separated small and large fiefholders, large fiefholders were given a lower ranking based on the possibility that they may be receiving revenues from more than one villages and thus less able to attend each village closely. Sometimes the records did not further distinguish between two or more recipients, for example by lumping together fiefholders and pious foundations in one category, in which case we assigned them an equal ranking.

${ }^{17}$ See Kunt (1983: 20) for a discussion of the relationship between the size of a tax source and its allocation among recipients. 
( 1 if divided between two or more revenue holders). The productivity of economic activities could also be a factor. Because the number of taxpayers was the only input item consistently recorded among provinces, we used the information about taxpayers and their taxes to estimate the revenue of economic activities per taxpayer in a village and used it as a proxy for the village's productivity. Finally, when the data spanned a geographically wide and diverse area, we used dummy variables to control for the effect of various unobservable (such as political) differences among districts.

Table 3 shows the results of ordered probit analysis of influences on tax assignment in five representative regions of the Empire, some at different points in time. The effects of control variables are generally in expected directions. The coefficient of the number of taxpayers is generally positive and significant, which shows that larger villages were more likely than smaller ones to be assigned to distant recipients and confirms the expectation about the importance of economies of scale in tax collection. The generally negative (though not always significant) coefficients of the "Revenue Divided" dummy variable are also consistent with the expectations. That divided revenues were less likely to be assigned to distant recipients indicates that the central and provincial governments were less able than others to deal with the requisite costs of division and the state considered these differential abilities in allocating divided revenues. The coefficients of productivity are also generally positive (in all regions other than Malatya), indicating that more productive tax revenues were more likely to be allocated to central and provincial governments than pious foundations and fiefholders (though the effect is not very significant in some regions). Because of space constraints, the results of the dummy variables that account for unobservable differences among the districts are not reported in the table. 
Controlling for other influences makes it possible to isolate the individual effect of the focus variable: the proportion of output and trade taxes. The coefficient of the proportion is negative and significant at conventional levels in most regions, providing strong support for the transaction costs hypothesis of revenue allocation. The risk hypothesis receives some support only in Antep, where the coefficient is positive and significant in 1536 and 1543. Unfortunately, the data do not include sufficient information about the peculiar circumstances of the region that can explain why the risk effect dominated the transaction cost effect in revenue allocation. Although the consistently positive coefficient of the proportion of output and trade taxes in Antep show that the relative merits of risk and transaction costs hypotheses could vary significantly among regions, negative coefficients in other regions indicate that the transaction cost was generally the dominant consideration in tax assignment.

The dominance of the transaction cost effect raises the question of why the risk effect was small. Risk considerations may have had an insignificant effect on the assignment of taxes because the recipients had various alternatives to insure against fluctuations in income. One possibility in smoothing consumption over time was to store grain or cash income as a means of self insurance. Just as the central government could insure income by diversifying tax revenues across regions, a small fiefholder could diversify over time by storage. Another possibility was for tax recipients to participate in formal or informal institutions of credit. ${ }^{18}$ Although there were various similar mechanisms to insure against risk, there were no feasible alternatives to reduce transaction costs. Various knowledge and incentive constraints and agency costs made it infeasible to rely on alternatives like self-reporting to resolve the problem of accurate

\footnotetext{
${ }^{18}$ Fenoaltea (1976) uses a similar line of reasoning to criticize risk-based explanations of scattering on Open Fields.
} 
measurement of the tax base. Other alternatives like stiff penalties for underreporting and mutual or external monitoring must have been similarly infeasible.

\section{CONCLUSION}

A quantitative analysis of the allocation of Ottoman tax revenues shows that tax assignment was influenced more by transaction costs than risks. To test the competing claims of the risk and transaction costs hypotheses quantitatively, we used data from the sixteenth century tax registers of the Ottoman Empire in five regions. We constructed an ordinal independent variable to represent a recipient's relationship to the source of tax and used an ordered probit model to identify how the proportion of variable (risky, high in transaction cost) taxes affected tax assignment. In all but one region the results support the transaction costs hypothesis. The relative insignificance of risk considerations suggests that tax recipients generally had various feasible alternatives in insuring against risky incomes. But in dealing with transaction costs they had no better alternatives than to assign costlier taxes to those who can bear them more efficiently. 


\section{WORKS CITED}

- Akgündüz, Ahmed. 1990. Osmanlı Kanunnâmeleri ve Hukukî Tahlilleri. İstanbul: Osmanlı Araştırmaları Vakfı.

- Allen, Douglas W. 1998. "Cropshare Contracts," in Peter Newman, ed. The New Palgrave Dictionary of Economics and the Law. New York: Stockton Press.

- Allen, Douglas W. and Dean Lueck. 1993. "Transaction Costs and the Design of Cropshare Contracts," RAND Journal of Economics 24: 78-100.

- Alston, Lee J. 2003. "Tenant Farming," in Joel Mokyr, editor in chief, Oxford Encyclopedia of Economic History, 5: 97-101.

- Alston, Lee J. and Robert Higgs. 1982. "Contractual Mix in Southern Agriculture since the Civil War: Facts, Hypotheses, and Tests," Journal of Economic History 42(2): 327-53.

- Aronsson, Thomas and Magnus Wikström, 2003. "Optimal Taxation and Risk-Sharing Arrangements in an Economic Federation," Oxford Economic Papers 55: 104-20.

- Barkan, Ömer Lütfi and Enver Meriçli, 1988. Hüdavendigâr Livası Tahrir Defterleri. I. Ankara:Türk Tarih Kurumu.

- Barkan, Ömer Lütfi. 1943. XV ve XVI. Asırlarda Osmanlı İmparatorluğunda Zirai Ekonominin Hukuki ve Mali Esasları. Cilt 1: Kanunlar Istanbul Üniversitesi yayınlarından. Edebiyat Fakültesi Türkiyat Enstitüsü Neşriyatı. Istanbul, Burhaneddin Matbaasi.

- Barzel, Yoram. 1982. "Measurement Cost and the Organization of Markets," The Journal of Law and Economics 25(1): 27-48.

- Cheung, Steven N. S. 1969. The Theory of Share Tenancy. Chicago: The University of Chicago Press.

- Coşgel, Metin M. 1992. "Risk Sharing in Medieval Agriculture," Journal of European Economic History 21(1): 99-110.

- Coşgel, Metin M. 2003. “Ottoman Tax Registers (Tahrir Defterleri),” Historical Methods, forthcoming.

- Darling, Linda. 1996. Revenue-Raising and Legitimacy: Tax Collection and Finance Administration in the Ottoman Empire, 1560-1660. NY: E.J. Brill.

- Fenoaltea, Stefano. 1976. "Risk, Transaction Costs and the Organization of Medieval Agriculture," Explorations in Economic History, pp. 129-52.

- Göyünç, Nejat and Wolf-Dieter Hütteroth. 1997. Land an der Grenze. Istanbul: Eren Yayıncilık.

- Hütteroth, Wolf-Dieter and Kamal Abdalfattah. 1977. Historical Geography of Palestine, Transjordan and Southern Syria in the Late 16th Century. Erlanger Geographische Arbeiten, Vol. 5, Erlangen.

- Hoff, Karla, Avishay Braverman, and Joseph E. Stiglitz, eds. 1993. The Economics of Rural Organization: Theory, Practice, and Policy. New York: Oxford University Press.

- İnalc1k, Halil. 1959. “Osmanlılarda Raiyyet Rüsumu,“ Belleten Cilt 23, Say1 92, pp. 575610.

- İnalc1k, Halil. 1973. The Ottoman Empire: The Classical Age, 1300-1600. London: Phoenix Press. 
- Inalc1k, Halil. 1994. [with Donald Quataert]. An Economic and Social History of the Ottoman Empire, 1300-1914. New York: Cambridge University Press.

- Kazıc1, Ziya. 1977. Osmanlılarda Vergi Sistemi. İstanbul: Şamil Yayınevi.

- Kunt, I. Metin. 1983. The Sultan's Servants. New York: Columbia University Press.

- Løkkegaard, Frede. 1950. Islamic Taxation in the Classic Period, with Special Reference to Circumstances in Iraq. Copenhagen: Branner and Korch.

- Lambton, A.K.S. 1962. "Kharādj," Encyclopaedia of Islam. Second Edition. Leiden.

- McCloskey, D. N. 1976. "English Open Fields as Behavior toward Risk," in P. Uselding, ed., Research in Economic History, 1: 124-170.

- McLure, Charles E., Jr. ed. 1983. Tax Assignment in Federal Countries. Canberra: Australian National University.

- Özdeğer, Hüseyin. 1988. Onaltıncı Asırda Ayıntab Livası İstanbul.

- Patashnik, Eric M. 1996. "The Contractual Nature of Budgeting: A Transaction Cost Perspective $\mathrm{n}$ the Design of Budgeting Institutions," Policy Sciences 29: 189-212.

- Persson, Karl Gunnar. 2003. "Agricultural Risk Management: Historical Overview," In Joel Mokyr, editor in chief, Oxford Encyclopedia of Economic History, 1: 49-53.

- Stiglitz, Joseph E. 1974 "Incentives and Risk Sharing in Sharecropping," Review of Economic Studies 41: 219-56.

- Yinanç, Rafet and Mesut Elibüyük. 1983. Kanuni Devri Malatya Tahrir Defteri (1560) Ankara 
TABLE 1

EXAMPLES OF TAXES AND RATES IN OTTOMAN DISTRICTS

\begin{tabular}{|c|c|c|c|c|c|c|c|}
\hline & \multicolumn{5}{|c|}{ FIXED TAXES } & \multicolumn{2}{|c|}{$\begin{array}{l}\text { VARIABLE } \\
\text { TAXES }\end{array}$} \\
\hline & \multicolumn{3}{|c|}{ Personal Taxes } & \multicolumn{2}{|c|}{ Input Taxes } & Trade & Output \\
\hline & $\begin{array}{c}\text { Yoke Tax } \\
\text { [Resm-i } \\
\text { Çift] }\end{array}$ & $\begin{array}{c}\text { Bachelor } \\
\text { Tax } \\
\text { [Resm-i } \\
\text { Mücerred] }\end{array}$ & $\begin{array}{c}\text { Gate Tax } \\
\text { [Resm-i } \\
\text { Kapu] }\end{array}$ & $\begin{array}{c}\text { Animal } \\
\text { Products }\end{array}$ & $\begin{array}{c}\text { Vineyar } \\
d s\end{array}$ & $\begin{array}{c}\text { Examples } \\
\text { of Goods } \\
\text { Brought to } \\
\text { Market }\end{array}$ & Tax Rate \\
\hline Antep (1574) & 40 & 6 & & $\begin{array}{c}0.5 / \\
\text { animal }\end{array}$ & $\begin{array}{l}0.02 / \\
\text { vine }\end{array}$ & $\begin{array}{l}1 / \text { camel- } \\
\text { load of } \\
\text { miscellane } \\
\text { ous goods }\end{array}$ & $1 / 10$ \\
\hline $\begin{array}{l}\text { Budapest } \\
\text { (1562) }\end{array}$ & & & 50 & $\begin{array}{c}0.5 / \\
\text { animal }\end{array}$ & 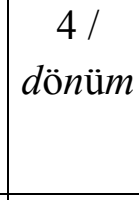 & $\begin{array}{c}4 / \text { wagon- } \\
\text { load of } \\
\text { pots and } \\
\text { cups }\end{array}$ & $1 / 10$ \\
\hline Bursa (1521) & 33 & 9 or 12 & & $\begin{array}{c}0.5 / \\
\text { animal }\end{array}$ & 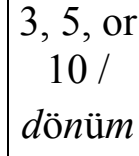 & & $1 / 10$ \\
\hline Erbil (1542) & 50 & 6 & & $\begin{array}{c}0.5 / \\
\text { animal }\end{array}$ & & $\begin{array}{c}10 / \text { load } \\
\text { of butter } \\
\text { and honey }\end{array}$ & \\
\hline $\begin{array}{l}\text { Jerusalem } \\
(\mathbf{1 5 6 2 )}\end{array}$ & & & & $\begin{array}{c}0.5 / \\
\text { animal }\end{array}$ & $\begin{array}{l}0.1 / \\
\text { vine }\end{array}$ & $\begin{array}{c}20 / \text { camel- } \\
\text { load of } \\
\text { linen }\end{array}$ & $1 / 7-2 / 5$ \\
\hline $\begin{array}{l}\text { Malatya } \\
(1560)\end{array}$ & 50 & 6 & & $\begin{array}{c}0.5 / \\
\text { animal }\end{array}$ & $\begin{array}{c}0.03 / \\
\text { vine }\end{array}$ & & $1 / 5$ \\
\hline
\end{tabular}

Notes: All monetary values are in the Ottoman currency of $A k c ̧ e$. Dönüm is a measure of land. See the text for the definitions of personal tax items. Some figures are missing either because the tax code ( $k \bar{a} n \overline{\mathrm{u}} n n \bar{a} m e)$ did not specify the rate for those items or because the description was too detailed and complex to be summarized in a single entry. Because of the customized nature of lumpsum enterprise taxes, their rates are not reported.

Sources: Ottoman provincial tax codes. Akgündüz (1990), Barkan (1943). 
TABLE 2

THE DISTRIBUTION OF TAX REVENUES

\begin{tabular}{lcccc}
\hline & \multicolumn{5}{c}{$\begin{array}{c}\text { PROVINCIAL AND } \\
\text { DISTRICT } \\
\text { REGION (YEAR) }\end{array}$} & $\begin{array}{c}\text { CENTRAL } \\
\text { GOVERNMENT }\end{array}$ & $\begin{array}{c}\text { GOVERNMENTS } \\
\text { FIEFHOLDERS OTHERS }\end{array}$ \\
\hline Antep (1536) & 0.35 & 0.29 & 0.27 & 0.09 \\
Antep (1543) & 0.47 & 0.14 & 0.27 & 0.13 \\
Antep (1574) & 0.35 & 0.04 & 0.40 & 0.10 \\
Bursa (1521) & 0.40 & 0.04 & 0.18 & 0.39 \\
Bursa (1573) & 0.26 & 0.17 & 0.31 & 0.39 \\
Malatya (1560) & 0.37 & 0.15 & 0.18 & 0.28 \\
Mardin (1564) & 0.50 & 0.12 & 0.26 & 0.10 \\
Palestine, Transjordan, & 0.21 & & 0.46 & 0.20 \\
Southern Syria (1596) & & & & \\
\hline
\end{tabular}

Notes: Recipients in the "Others" category include private landholders, pious foundations, and tribes.

Sources: Ottoman Tapu Tahrir Defterleri (numbered 44, 111, 113, 161, 186, 373, 406, 453, and 1050 in the Prime Ministry Archives in Istanbul and 67, 68, 72, 75, 80, 97, 100, 112, 117, 142, $181,185,192,570,580$, and 585 in the Cadastral Office in Ankara; contents published by Özdeğer (1988), Barkan and Meriçli (1988), Yinanç and Elibüyük (1983), Göyünç and Hütteroth (1997), and Hütteroth and Abdalfattah (1977). 


\section{TABLE 3 \\ ORDERED PROBIT ESTIMATES OF INFLUENCES ON THE DISTRIBUTION OF TAX REVENUE}

\begin{tabular}{|c|c|c|c|c|c|c|}
\hline REGION (YEAR) & $\begin{array}{c}\text { Proportion } \\
\text { of Variable } \\
\text { Taxes }\end{array}$ & $\begin{array}{c}\text { Number of } \\
\text { Adult } \\
\text { Males }\end{array}$ & $\begin{array}{c}\text { Output } \\
\text { per Adult } \\
\text { Male }\end{array}$ & $\begin{array}{c}\text { Multiple } \\
\text { Recipients } \\
\text { Share Tax } \\
\text { Revenue }\end{array}$ & $\mathbf{N}$ & $\begin{array}{c}\text { Log } \\
\text { Likelihood }\end{array}$ \\
\hline Antep (1536) & $\begin{array}{c}0.02 \\
(0.90)\end{array}$ & $\begin{array}{l}0.004 \\
(0.36)\end{array}$ & $\begin{array}{c}0.00009 \\
(0.16)\end{array}$ & $\begin{array}{c}0.14 \\
(0.51)\end{array}$ & 102 & -134.7 \\
\hline Antep (1543) & $\begin{array}{c}0.38 \\
(0.04)\end{array}$ & $\begin{array}{l}0.007 \\
(0.02)\end{array}$ & $\begin{array}{c}0.00008 \\
(0.08)\end{array}$ & $\begin{array}{l}-0.15 \\
(0.15)\end{array}$ & 220 & -314.1 \\
\hline Antep (1574) & $\begin{array}{c}0.50 \\
(0.01)\end{array}$ & $\begin{array}{c}0.03 \\
(<0.001)\end{array}$ & $\begin{array}{c}0.0002 \\
(<0.001)\end{array}$ & $\begin{array}{l}-0.04 \\
(0.01)\end{array}$ & 212 & -330.2 \\
\hline Bursa (1521) & $\begin{array}{l}-0.63 \\
(0.08)\end{array}$ & $\begin{array}{l}0.004 \\
(0.32)\end{array}$ & $\begin{array}{l}0.00005 \\
(0.001)\end{array}$ & & 329 & -275.1 \\
\hline Bursa (1573) & $\begin{array}{l}-2.13 \\
(0.05)\end{array}$ & $\begin{array}{l}0.007 \\
(0.26)\end{array}$ & $\begin{array}{c}0.00008 \\
(0.14)\end{array}$ & & 933 & -663.3 \\
\hline Malatya (1560) & $\begin{array}{c}-0.26 \\
(0.008)\end{array}$ & $\begin{array}{l}-0.001 \\
(0.45)\end{array}$ & $\begin{array}{c}-0.00002 \\
(0.05)\end{array}$ & $\begin{array}{l}-0.12 \\
(0.25)\end{array}$ & 620 & -893.9 \\
\hline Mardin (1564) & $\begin{array}{c}-0.35 \\
(<0.001)\end{array}$ & $\begin{array}{c}0.004 \\
(0.002)\end{array}$ & $\begin{array}{c}0.00003 \\
(0.46)\end{array}$ & $\begin{array}{c}-0.44 \\
(<0.001)\end{array}$ & 1670 & -2203.7 \\
\hline $\begin{array}{l}\text { Palestine, } \\
\text { Transjordan, } \\
\text { Southern Syria (1596) }\end{array}$ & $\begin{array}{l}-0.93 \\
(0.05)\end{array}$ & $\begin{array}{c}0.004 \\
(0.002)\end{array}$ & $\begin{array}{c}0.0002 \\
(<0.001)\end{array}$ & $\begin{array}{c}-0.02 \\
(0.93)\end{array}$ & 1352 & -1386.3 \\
\hline
\end{tabular}

Notes: Figures in parentheses are the p-values. The dependent variable is an ordinal variable that takes the value of a recipient's rank in the following (ascending) order, based on the recipients' relative "distance" to the tax source: private landholders, (small and large) fiefholders, pious foundations, district and provincial governments, and the central government. See the text for the descriptions of independent variables. Because of space constraints, the results of the dummy variables that account for unobservable differences among districts are not reported.

Sources: Ottoman Tapu Tahrir Defterleri (numbered 44, 111, 113, 161, 186, 373, 406, 453, and 1050 in the Prime Ministry Archives in Istanbul and 67, 68, 72, 75, 80, 97, 100, 112, 117, 142, $181,185,192,570,580$, and 585 in the Cadastral Office in Ankara; contents published by Özdeğer (1988), Barkan and Meriçli (1988), Yinanç and Elibüyük (1983), Göyünç and Hütteroth (1997), and Hütteroth and Abdalfattah (1977). 